\title{
THE EFFECT OF LOCAL VIBROSTIMULATION ON ELECTROMYOGRAPHY PARAMETERS IN ROWERS
}

\author{
Kalvis Ciekurs \\ Latvian Academy of Sport Education \\ Viesturs Krauksts \\ Latvian Academy of Sport Education \\ Daina Krauksta \\ Latvian Academy of Sport Education \\ Baiba Smila \\ Latvian Academy of Sport Education \\ Aivars Kaupuzs \\ Rezekne Academy of Technologies
}

\begin{abstract}
Local vibrostimulation (further in text - $L V$ ) is innovation as a part of training method that helps athletes to regain the power and get ready for next training faster. There are many discussions about how to increase moving speed in rowers. Many scientists research the possibilities of increasing moving speed in this sport. The following methods were used in the study: tests - Concept-2, LV manipulations, electromyography and mathematical statistics. The electromyography was made with Biometric LTD. LV manipulations were done to the muscles erector spinae, latisimus dorsi, teres major, teres minor, trapezius, infraspinatus, deltoideus, slenius capitis, triceps brachii, gluteus maximus, semitendinosus, biceps femoris, semimembranosus, castrocnemius, tendo calcaneus, rectus femoris, vastus lateralis, tensor fascia latae, vastus medialis, sarterius, ligamentum patellae, tibialis anterior, rectus abdominis, pectoralis major and biceps brachii. We using $100 \mathrm{~Hz}$ frequency, 2 - $4 \mathrm{~mm}$ amplitude and different pressure on the muscles. The total LV application time was 5 to $20 \mathrm{~min}$. The obtained data were processed using mathematical statistics. The results: having stated the result difference before LV and after it. The results testify significant improvement of Concept-2 tests results and electromyography results, what is showed by the difference of the mean results. Comparing the results of the rowers of $E G$ and $C G$ they have differences in the left side muscle latissimus dorsi after the $t$-test where $p>0.05$, but stating the percentage of the mean result difference of this muscle it was found out that $p>0.05$ what also shows significant changes in the muscle biopotential $(\mathrm{mV})$.
\end{abstract}

Keywords: electromyography, local vibrostimulation, rowers. 


\section{Introduction}

In rowing, as in any sport, dominant physical abilities, necessary for the definite sport, are emphasized. In rowing the basic physical abilities are endurance and strength. It is much spoken about and researched how to increase the speed of moving in rowing. As one of the ways how to solve the problem the local vibration application before and after competitions, as well as during training sessions, is offered. Many scientists as (Kleshnev, 2010a; 2011., Hawkins, 2000., Hofmijster, 2010., Nolte, 2011., Nilsson, 1977), a.o. have researched the possibilities of increasing the speed of moving in rowing. Most part of researches is based on oxygen maximal consumption and other physiological changes during a load. Although there are various researches, stating the technical nuances of leg and arm work, comparatively little attention is paid to the role of the arm work. The cycle length in different distances and having different water flow - before the wind, against the wind and with the side wind is stated. Aim of the research the development of local vibration training application methodology and its approbation, the study of its effect on the muscle electromyography parameters. Hypothesis of the research - as a result of long-term local vibration (during three months), but of short-term impact, more effective muscle biopotential $(\mathrm{mV})$ dynamics. The attempts to combine vibration loads with traditional strength trainings with the purpose to achieve greater increase of the work capacity of the neuro - muscular system than only using classical strength trainings have already been carried out comparatively long ago. Recent research gives notion about the fact that vibration trainings both in acute or chronic form have explicitly positive effect on strength and power expressions in athlete whole preparation process. It is considered that it is possible to excellently observe muscle biopotential (mV) at different loads by the electromyograph, as well as to observe muscle fatigue after loads (Knipše, 2009; Kleshnev, 2010b). To state the training process and its usefulness for top rowers it is necessary to state muscle biopotential $(\mathrm{mV})$ and frequency $(\mathrm{Hz})$ during a stroke and relaxation what is essential precondition for renewal between the strokes (Nowicky, 2005, Schaar, 2010). The epidermal electrodes were used in the research which registered muscle biopotential $(\mathrm{mV})$ and frequency $(\mathrm{Hz})$.

\section{Methodology}

To state the effectiveness of the local vibration on rowers' muscles biopotentials the experimental group (further in text - EG) and the control group (further in text - CG) were form including the students of Murjani Sport Gymnasium (further in text - MSG) in the period of November 13, 2010 up to March, 2011. MSG students were chosen because they all train according to the 
similar system, as well as their daily routine is similar, too. 15 MSG students were chosen in the experimental group and $12 \mathrm{MSG}$ students in the control group, the age was $18-24$, on average $19.6 \pm 1.45$ years (EG) and $19.3 \pm 1.72$ years $(C G)$, having different experience in rowing. The height of the participants of EG was on average $190.7 \pm 3.4 \mathrm{~cm}$, but of CG $189.0 \pm 2.7 \mathrm{~cm}$, but the weight of the participants of EG was on average $88.0 \pm 5.0 \mathrm{~kg}$ and of CG it was $88.3 \pm 3.4 \mathrm{~kg}$. Performing of the first test on the stationary ergometer Concept- 2 and additionally stating of electromyography (EMG) (figure 1) what was held from 13.11.2010 up to 30.11.2010. And restarting second tests 08.03 .2011 up to 11.03.2011 on the stationary ergometer Concept-2 and making of electromyography after LV. The methodology of local vibration trainings was developed for the following muscles: erector spinae, latisimus dorsi, teres major, teres minor, trapezius, infraspinatus, deltoideus, slenius capitis, triceps brachii, gluteus maximus, semitendinosus, biceps femoris, semimembranosus, castrocnemius, tendo calcaneus, rectus femoris, vastus lateralis, tensor fascia latae, vastus medialis, sarterius, ligamentum patellae, tibialis anterior, rectus abdominis, pectoralis major un biceps brachii.

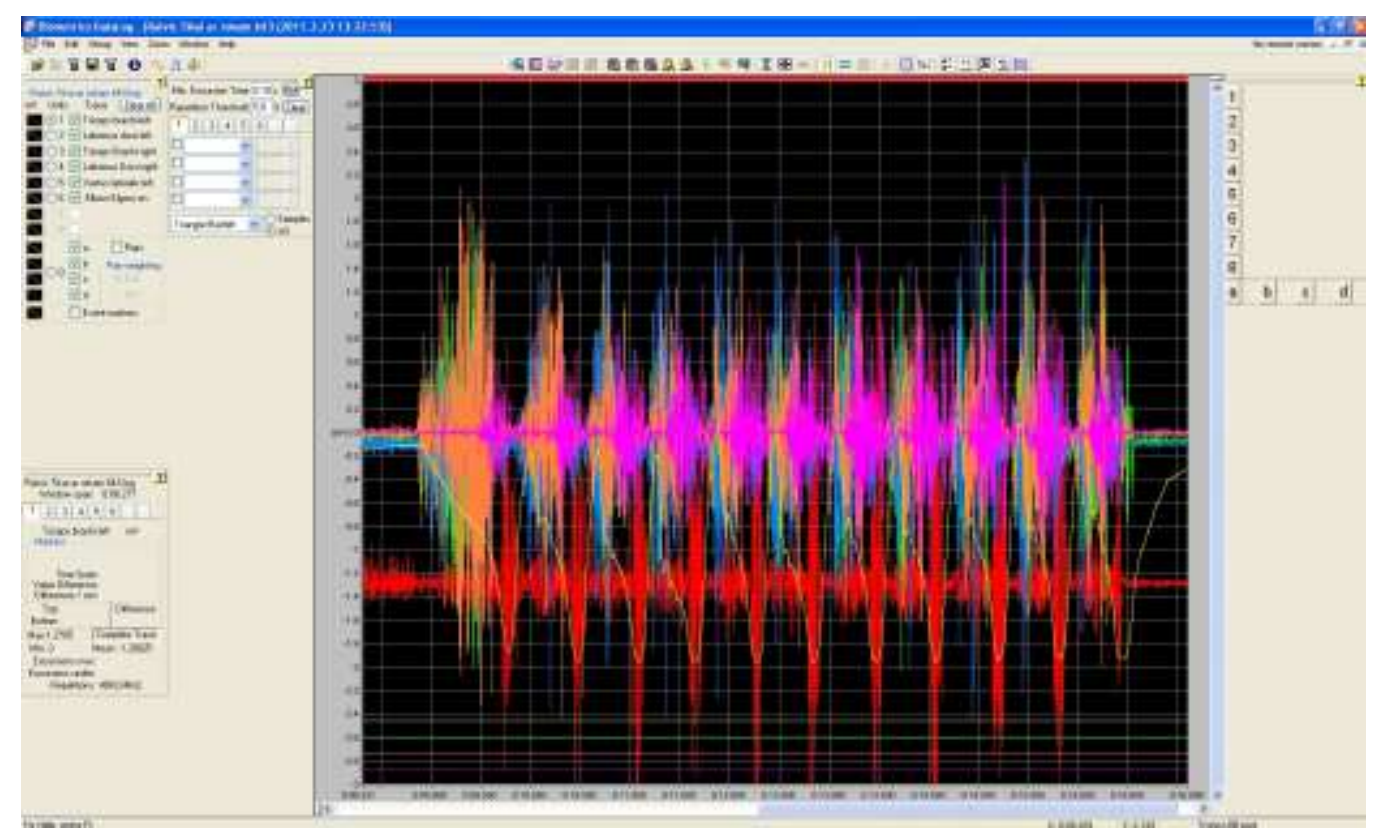

Figure 1 Electromyography in anaerobic power test

The trainings of local vibration to the whole body applied on the experimental group participants were held. The sessions of local vibration (Table 1) were held according to the methodology developed together with Prof. V. Krauksts. 
Kalvis Ciekurs, Viesturs Krauksts, Daina Krauksta, Baiba Smila, Aivars Kaupuzs. The Effect of Local Vibrostimulation on Electromyography Parameters in Rowers

Table 1 Scheme of local vibration for Murjani Gymnasium athletes

\begin{tabular}{|c|c|c|c|c|}
\hline Week & $\begin{array}{c}\text { Vibration } \\
\text { frequency }\end{array}$ & $\begin{array}{c}\text { Vibration } \\
\text { amplitude }\end{array}$ & $\begin{array}{c}\text { Vibration length in } \\
\text { minutes }\end{array}$ & $\begin{array}{c}\text { Vibration } \\
\text { times a week }\end{array}$ \\
\hline Week 1 & $100 \mathrm{~Hz}$ & $2 \mathrm{~mm}$ & $5 \mathrm{~min}$ & 2 \\
\hline Week 2 & $100 \mathrm{~Hz}$ & $2 \mathrm{~mm}$ & $5 \mathrm{~min}$ & 3 \\
\hline Week 3 & $100 \mathrm{~Hz}$ & $2 \mathrm{~mm}$ & $10 \mathrm{~min}$ & 2 \\
\hline Week 4 & $100 \mathrm{~Hz}$ & $2 \mathrm{~mm}$ & $10 \mathrm{~min}$ & 3 \\
\hline Week 5 & $100 \mathrm{~Hz}$ & $4 \mathrm{~mm}$ & $12 \mathrm{~min}$ & 2 \\
\hline Week 6 & $100 \mathrm{~Hz}$ & $4 \mathrm{~mm}$ & $12 \mathrm{~min}$ & 3 \\
\hline Week 7 & $100 \mathrm{~Hz}$ & $4 \mathrm{~mm}$ & $15 \mathrm{~min}$ & 2 \\
\hline Week 8 & $100 \mathrm{~Hz}$ & $4 \mathrm{~mm}$ & $15 \mathrm{~min}$ & 3 \\
\hline Week 9 & $100 \mathrm{~Hz}$ & $4 \mathrm{~mm}$ & $20 \mathrm{~min}$ & 2 \\
\hline Week 10 & $100 \mathrm{~Hz}$ & $4 \mathrm{~mm}$ & $20 \mathrm{~min}$ & 3 \\
\hline Week 11 & $100 \mathrm{~Hz}$ & $4 \mathrm{~mm}$ & $15 \mathrm{~min}$ & 3 \\
\hline Week 12 & $100 \mathrm{~Hz}$ & $4 \mathrm{~mm}$ & $15 \mathrm{~min}$ & 4 \\
\hline
\end{tabular}

\section{Results of research}

Anaerobic power was stated in watts (W) according to the indicators of the digital monitor of Concept-2. But the changes of EMG (electromyography) activity or electric impulse amplitude changes were stated in millivolts (muscle biopotential $(\mathrm{mV})$ ). With the help of goniometre the movement beginning of the brace phase was fixed when stating the muscle triceps brachi and latisimus dorsi boipotentials $(\mathrm{mV})$ before flexing the arm in the elbow and also during the flexion time. For both EG and CG t-test $(\mathrm{p}=0.802)$ was stated, where the results of the group means were for $\mathrm{EG}-610.8 \mathrm{~W}$ and for $\mathrm{CG}-621.8 \mathrm{~W}$, what proved that both groups are similar. Stating the reached maximal anaerobic power in the test, it was found that on average the rowers reached after $6.2 \mathrm{~s}$ what is actually identical with the rowing results on water where maximal anaerobic power or the maximal moving speed of a boat is shown $5-7 \mathrm{~s}$ (Kleshnev, 2011).

Analysing EMG (electromyography) data with the Independent Samples test it was found out that only in one case the data of EG and CG are different (Table 2 ) where the impulse frequency $(\mathrm{Hz})$ of the left side muscle latisimus dorsi was recorded lower than 0.05 , respectively t-test $p=0.007$. In other cases the results of both groups are similar, thus, also when analysing the data of the means, proving that the groups are similar. To state the result differences between EG and CG $t$-test Independent Samples Test was carried out which confirms the result differences between shown results on the stationary rowing ergometer Concept-2 where $p=0.003$ (Table 3). Stating the difference of percentage relation it was found out that the differences were observed for the muscle latisimus dorsii of the left side of the body where before the beginning of the movement $p=0.015$, but 
during the execution of the movement $\mathrm{p}=0.000$, but researching other muscles the differences of percentage relation were not observed.

Table 2 T-test Independent Samples test $\mathbf{p}$-values in the 1st anaerobic power test

\begin{tabular}{|l|c|c|c|c|}
\hline \multicolumn{1}{|c|}{ Muscle } & $\begin{array}{c}\text { Frequency } \\
\text { Hz before } \\
\text { beginning of } \\
\text { movement }\end{array}$ & $\begin{array}{c}\text { Frequency } \mathrm{Hz} \\
\text { during movement } \\
\text { execution }\end{array}$ & $\begin{array}{c}\text { Biopotential } \\
\text { mV before } \\
\text { beginning of } \\
\text { movement }\end{array}$ & $\begin{array}{c}\text { Biopotential } \mathrm{mV} \\
\text { during } \\
\text { movement } \\
\text { execution }\end{array}$ \\
\hline $\begin{array}{l}\text { Musculus triceps } \\
\text { brachii (LSB) }\end{array}$ & 0.435 & 0.752 & 0.568 & 0.455 \\
\hline $\begin{array}{l}\text { Musculus latisimus } \\
\text { dorsii } \text { (RSB) }\end{array}$ & 0.203 & 0.007 & $0.436^{*}$ & $0.318^{*}$ \\
\hline $\begin{array}{l}\text { Musculus triceps } \\
\text { brachii (LSB) }\end{array}$ & 0.828 & 0.870 & 0.554 & 0.645 \\
\hline $\begin{array}{l}\text { Musculus latisimus } \\
\text { dorsi } \text { (RSB) }\end{array}$ & 0.121 & 0.101 & 0.663 & $0.303^{*}$ \\
\hline
\end{tabular}

$(*)$ - percentage average $\mathrm{p}$ - value

(LSB - left side of body, RSB - right side of body)

Table 3 T-test Independent Samples Test $\mathbf{p}$ - values in anaerobic power 1 st and $2 \mathrm{nd}$ test

\begin{tabular}{|l|c|c|c|c|}
\hline \multicolumn{1}{|c|}{ Muscle } & $\begin{array}{c}\text { Frequency } \mathrm{Hz} \\
\text { before } \\
\text { beginning of } \\
\text { movement }\end{array}$ & $\begin{array}{c}\text { Frequency } \mathrm{Hz} \\
\text { during movement } \\
\text { execution }\end{array}$ & $\begin{array}{c}\text { Biopotential } \mathrm{mV} \\
\text { before beginning } \\
\text { of movement }\end{array}$ & $\begin{array}{c}\text { Biopotential } \mathrm{mV} \\
\text { during movement } \\
\text { execution }\end{array}$ \\
\hline $\begin{array}{l}\text { Musculus triceps } \\
\text { brachii (LSB) }\end{array}$ & 0.008 & 0.142 & 0.042 & 0.178 \\
\hline $\begin{array}{l}\text { Musculu slatisimus } \\
\text { dorsii (RSB) }\end{array}$ & 0.003 & 0.000 & $0.595^{*}$ & $0.229^{*}$ \\
\hline $\begin{array}{l}\text { Musculus triceps } \\
\text { brachii (LSB) }\end{array}$ & 0.002 & 0.154 & 0.021 & 0.016 \\
\hline $\begin{array}{l}\text { Musculus latisimus } \\
\text { dorsi (RSB) }\end{array}$ & 0.025 & \multirow{2}{*}{0.014} & 0.151 & $0.000^{*}$ \\
\cline { 4 - 5 } & & & $0.913^{*}$ & 0.159 \\
\cline { 4 - 5 } & & & $0.284^{*}$ & $0.891^{*}$ \\
\hline
\end{tabular}

(*) - percentage average $\mathrm{p}$ - value

(LSB - left side of body, RSB - right side of body)

Stating the percentage relation the average $\mathrm{p}$ - value, it was concluded that the muscles of the right side of the body triceps brachii un latissimus dorsi have differences what it shown by triceps brachii before the beginning of the movement execution where $\mathrm{p}=0.019$ and during the execution of the movement $\mathrm{p}=0.003$ (Table 4), but latissimus dorsi before the beginning of the movement execution $p=0.000$ and during the execution of the movement 0.028 . However, changes were not stated for the muscles of the left side of the body. The results testify that significant changes were observed in $\mathrm{CG}$ anaerobic power test for both muscles of the right side. 
Kalvis Ciekurs, Viesturs Krauksts, Daina Krauksta, Baiba Smila, Aivars Kaupuzs. The Effect of Local Vibrostimulation on Electromyography Parameters in Rowers

\section{Table 4 CG T-test Paired Samples Test and ANOVA Homogeneity of Variance Test p-values in anaerobic power 1 st and 2 nd test}

\begin{tabular}{|c|c|c|c|c|}
\hline Muscle & $\begin{array}{c}\text { Frequency } \\
\text { Hz before } \\
\text { beginning of } \\
\text { movement }\end{array}$ & $\begin{array}{l}\text { Frequency } \mathrm{Hz} \\
\text { during } \\
\text { movement } \\
\text { execution }\end{array}$ & $\begin{array}{l}\text { Biopotential } \mathrm{mV} \\
\text { before beginning } \\
\text { of movement }\end{array}$ & $\begin{array}{c}\text { Biopotential } \mathrm{mV} \\
\text { during } \\
\text { movement } \\
\text { execution } \\
\end{array}$ \\
\hline \multirow{2}{*}{$\begin{array}{l}\text { Musculus triceps } \\
\text { brachii (LSB) }\end{array}$} & \multirow{2}{*}{0.507} & \multirow{2}{*}{0.455} & 0.929 & 0.460 \\
\hline & & & $0.627 * *$ & $0.318 * *$ \\
\hline $\begin{array}{l}\text { Musculus triceps } \\
\text { brachii (LSB) }\end{array}$ & $0.614^{*}$ & $0.711^{*}$ & $0.940^{*}$ & $0.399 *$ \\
\hline \multirow{2}{*}{$\begin{array}{l}\text { Musculus latisimus } \\
\text { dorsii (LSB) }\end{array}$} & \multirow{2}{*}{0.095} & \multirow{2}{*}{0.042} & 0.098 & 0.228 \\
\hline & & & $0.313 * *$ & $0.811 * *$ \\
\hline $\begin{array}{l}\text { Musculus latisimus } \\
\text { dorsii (LSB) }\end{array}$ & $0.057^{*}$ & $0.133 *$ & $0.077^{*}$ & $0.386^{*}$ \\
\hline \multirow{2}{*}{$\begin{array}{l}\text { Musculus triceps } \\
\text { brachii (RSB) }\end{array}$} & \multirow{2}{*}{0.210} & \multirow{2}{*}{0.518} & 0.647 & 0.282 \\
\hline & & & $0.019 * *$ & $0.003 * *$ \\
\hline $\begin{array}{l}\text { Musculus triceps } \\
\text { brachii (RSB) }\end{array}$ & $0.362 *$ & $0.589 *$ & $0.761 *$ & $0.515^{*}$ \\
\hline \multirow{2}{*}{$\begin{array}{l}\text { Musculus latisimus } \\
\text { dorsi (RSB) }\end{array}$} & \multirow{2}{*}{0.070} & \multirow{2}{*}{0.068} & 0.078 & 0.026 \\
\hline & & & $0.000 * *$ & $0.028 * *$ \\
\hline $\begin{array}{l}\text { Musculus latisimus } \\
\text { dorsi (RSB) }\end{array}$ & $0.102 *$ & $0.215^{*}$ & $0.121 *$ & $0.182^{*}$ \\
\hline
\end{tabular}

$(*)$ - ANOVA test; $(* *)$ - percentage average $\mathrm{p}$ - value

(LSB - left side of body, RSB - right side of body)

Table 5 EG T-test Paired Samples Test p- values in anaerobic power 1st and 2 nd test

\begin{tabular}{|l|c|c|c|c|}
\hline \multicolumn{1}{|c|}{ Muscle } & $\begin{array}{c}\text { Frequency } \\
\text { Hz before } \\
\text { beginning of } \\
\text { movement }\end{array}$ & $\begin{array}{c}\text { Frequency Hz } \\
\text { during movement } \\
\text { execution }\end{array}$ & $\begin{array}{c}\text { Biopotential } \mathrm{mV} \\
\text { before beginning } \\
\text { of movement }\end{array}$ & $\begin{array}{c}\text { Biopotential mV } \\
\text { during movement } \\
\text { execution }\end{array}$ \\
\hline $\begin{array}{l}\text { Musculus triceps } \\
\text { brachii (LSB) }\end{array}$ & 0.000 & 0.000 & 0.001 & 0.000 \\
\hline $\begin{array}{l}\text { Musculus triceps } \\
\text { brachii (LSB) }\end{array}$ & $0.006^{*}$ & $0.017^{*}$ & $0.009^{*}$ & $0.019^{*}$ \\
\hline $\begin{array}{l}\text { Musculus latisimus } \\
\text { dorsii (LSB) }\end{array}$ & 0.095 & 0.067 & 0.448 & 0.123 \\
\hline $\begin{array}{l}\text { Musculus latisimus } \\
\text { dorsii (LSB) }\end{array}$ & $0.213^{*}$ & $0.099^{*}$ & $0.950^{* *}$ & $0.003^{* *}$ \\
\hline $\begin{array}{l}\text { Musculus triceps } \\
\text { brachii (RSB) }\end{array}$ & 0.000 & 0.015 & $0.412^{*}$ & $0.115^{*}$ \\
\hline $\begin{array}{l}\text { Musculus triceps } \\
\text { brachii (RSB) }\end{array}$ & $0.000^{*}$ & $0.016^{*}$ & 0.000 & 0.002 \\
\hline $\begin{array}{l}\text { Musculus latisimus } \\
\text { dorsi (RSB) }\end{array}$ & 0.442 & 0.139 & $0.000^{* *}$ & $0.000^{* *}$ \\
\hline $\begin{array}{l}\text { Musculus latisimus } \\
\text { dorsi (RSB) }\end{array}$ & $0.556^{*}$ & $0.173^{*}$ & 0.069 & 0.294 \\
\cline { 4 - 5 } & & $0.000^{* *}$ & $0.097^{* *}$ \\
\hline
\end{tabular}

$(*)$ - ANOVA test $(* *)$ - percentage average $p$ - value

LSB - left side of body, RSB - right side of body 
However, stating the differences of the percentage relations of biopotencials $(\mathrm{mV})$, they were stated for the left side muscles of the body latisimus dorsii. Taking a look at the results obtained from the t-test Paired Samples Test, there are can be seen changes in EG between the first and second test for the muscle triceps brachii before the beginning of the movement in the impulse frequencies $(\mathrm{Hz})$ field in both the left and right sides where $\mathrm{p}$ value is less than 0.05 , but in other cases the results were similar and more than 0.05. But for percentage relations in the impulse amplitude $(\mathrm{mV})$ field differences were found out for the right side muscles of the body latisimus dorsii before the beginning of the movement. Processing the data with ANOVA it was stated that in only one case the result difference was approved, specifically in triceps brachii innervations impulse frequencies $(\mathrm{Hz})$ field before the beginning of the movement $\mathrm{p}=0.002$. But stating CG t-test Paired Samples Test it is stated that only for the muscle latisimus dorsii of the left side of the body during the execution of the movement the frequency $(\mathrm{Hz}) \mathrm{p}=0.042$, but for the muscle latisimus dorsii of the right side of the body the impulse amplitude $(\mathrm{mV}) \mathrm{p}=0.026$ (Table 4). But stating the percentage differences of the muscles of the right side of the body they are found out in all cases, but are not observed for the muscles of the left side of the body. However, differences were not stated in ANOVA test. Analyzing the obtained data of muscle biopotential amplitude $(\mathrm{mV})$ and impulse frequency $(\mathrm{Hz})$ it is concluded that differences were observed in EG muscle triceps brachii both in the left and right side of the body in $t$-test Paired and in the ANOVA test in all cases (Table 5). In the muscle latisimus dorsii differences were not observed, although there was a tendency to have differences in t-test Paired muscle innervations impulse frequency $(\mathrm{Hz})$ field in the left side of the body both in the beginning of the movement and during the execution of the movement, as well as the ANOVA test showed a tendency in muscle innervations impulse frequency $(\mathrm{Hz})$ field during the execution of the movement. But the results for the muscle latisimus dorsii of the right side of the body show only the possible differences of impulse amplitude $(\mathrm{mV})$ before the beginning of the movement both in $t$-test Paired and ANOVA test where the result was close to different $p=0.052$. Stating the EMG obtained data it was found out that in EG electric activity had improved $(\mathrm{mV})$ in $m$. triceps brachii, but any essential changes were not observed in $m$. latisimus dorsi. In the research about electric activity different muscles have been studied (Kleshnev, 2010b; 2011).

\section{Conclusions}

1. In the anaerobic power test comparing the muscle innervations impulse biopotential $(\mathrm{mV})$ and muscle innervations impulse frequency $(\mathrm{Hz})$ the result 
differences of EG and CG rowers have been observed only in one case, but in other cases the result differences were not observed.

2. Stating the changes of the muscle innervations frequency $(\mathrm{Hz})$ and the changes of the biopotential $(\mathrm{mV})$ in the first and second test of EG it is concluded that the differences in the t-test are observed for both the left and right side muscles triceps brachii and latissimus dorsi. The ANOVA test testifies the result differences only in one muscle - triceps brachi.

3. Stating the credibility of the CG rowers' result difference by the t-test it is concluded that there is difference for the muscle latissimus dorsi innervations frequency $(\mathrm{Hz})$, but for the muscle biopotential $(\mathrm{mV})$ in the right side.

\section{Summary}

Many scientists in their researches have used different vibration frequencies, amplitude and time of vibration to determine the immediate and short term effect. The result analysis of the carried out research shows that the hypothesis forwarded for this research has partially proved to be true as stating the MSG rowers' results in anaerobic power test it is concluded that for the EG rowers the ability of maximal anaerobic power have significantly improved, proved by the results of the $t$-test and ANOVA analysis. The results of the CG rowers have also improved, however, having processed the obtained data using the t-test and ANOVA analysis it was stated that the results are similar, but significantly different (lower) in comparison with the dynamics of the EG rowers' results. Thus the positive effect of the local vibration on athletes' anaerobic power ability is proved. LV is effective and applicable in the training process in the strength development stage in winter - preparation period.

\section{References}

Hawkins, D. (2000). A new instrumentation system for training rowers. Journal of Biomechanics, 33 (2), 241-245.

Hofmijster, M. J. (2010). Mechanics and energetics of rowing. Faculty of Human Movement Sciences, 153.

Kleshnev, V. (2010). a. Rowing biomechanics newsletter. Nr. 107, Vol. 10.

Kleshnev, V. (2010). b. Rowing biomechanic newsleter.Nr. 114, Vol. 10.

Kleshnev, V. (2011). A brief history of our development in force measurement area. Retrieved fromhttp://www.biorow.com/PS_tel_files/History\%20of\%20Force.pdf.

Knipše, G. at al. (2009). Vēdera muskulatūras elektromiogrāfiskā aktivitāte fizisko vingrojumu laikā. Latvijas universitātes raksti - medicīna, 750 sējums. Lpp. 245. - 252.

Nilsson, J., Tesch, P., \& Thorstensson, A. (1977). Fatigue and EMG of repeated fast voluntary contractions in man. ActaPhysiologica, 101 (2), 194-198. 
Nolte, V. (2011). Rowing faster: serious training for serious rowers. Human Kinetics, Incorporated. P. $107-110$.

Nowicky, A. V., Burdett, R., \& Horne, S. (2005). The impact of ergometer design on hip and trunk muscle activity patterns in elite rowers: an electromyographic assessment. Journal of Sports Science and Medicine, 4, 18-28.

Schaar, H., \& Mattes, K. (2010). Comparison of the electromiographic activity patterns of elite rowers on the rowing ergometer and the Dyno. University of Hamburg, Germany, department of human movement. 